\title{
The Funnel Beaker Culture in Western Lesser Poland: Yesterday and Today
}

\author{
Marek Nowak $^{a}$
}

\begin{abstract}
Although Jan Kowalczyk's work on the Funnel Beaker culture (TRB) did not particularly refer to western Lesser Poland, many of his general and detailed reflections on Neolithic archaeology can be utilized to better characterise this culture in this territory. The TRB appeared there c. $3750 / 3700$ BC and existed until c. 2800 BC. "Funnel Beaker" acculturation of the late Lengyel-Polgár populations could play a large part in the origins of the local branch of this culture. For many years, the TRB seemed to be scarcely represented. This notion has changed since early I970s onwards, due to more and more intensive investigations. Currently, western Lesser Poland is perceived as an equally important region of the TRB development as other the most important ones both in Lowland and Upland zones. The local TRB communities were characterised by varied patterns of settlement and economic behaviours. These patterns were correlated with ecological differences.
\end{abstract}

KEY-WORDS: Funnel Beaker culture; western Lesser Poland; absolute chronology; Jan Kowalczyk.

I never had the opportunity to meet Jan Kowalczyk in person. This was due to generational disparities as well as due to us belonging to slightly different research schools. I encountered his name, of course, during my studies, when my archaeological specialization began to crystallize. It quickly became clear to me that he was an extraordinary figure that left a significant mark on Polish archaeology.

If we want to recollect Jan Kowalczyk, we should not only give him a good write-up. I believe that at present his achievements should be a call for us to reflect on the state of today's science (not only archaeology and prehistory) and ways it is practiced.

Kowalczyk's scholarly achievements reflect a situation completely unrelated to the current realities of scientific life. These realities are primarily a requirement to publish, publish and publish as much and as quickly as possible; and to publish only in such journals/books which provide a lot of "points" (publish or perish rule). Such an attitude is convenient for officials and politicians who manage science, and for evaluators and

a Institute of Archaeology, Jagiellonian University, II Gołębia st., 3I-007 Cracow, Poland, e-mail: marekiauj.nowak@uj.edu.pl ORCID: oooo-oooI-7220-6495 
experts of various types. What is the value of all this? Of course, very variable, because the quantity does not always turns into quality.

What is more, is anyone able to read these oceans of journals, books, pdfs, and so on? Are those who produce countless publications interested at all in science as such, i.e. in "discovering the truth", as it is pathetically but accurately described. The answer to both questions is obviously "no", but this is of concern to a few it seems. Officials are satisfied, as are those scholars that succumb to "pointosis", those who are still resisting become depressed and demotivated. And so it goes on.

Jan Kowalczyk and his works demonstrate that scholarship is something else. The point is that our printed publications should bring us closer to this "truth", and not become - after obtaining the appropriate number of points - merely scrap paper for recycling. The point is that each publication should be deeply thought out, discussed, carefully and clearly formulated (which does not mean that publications are to avoid far-reaching or even risky interpretations and hypotheses). The publications by Jan Kowalczyk were precisely of this kind. The fact that there were so few of them is of lesser importance. Each of them was a kind of a diamond that shines up to this day. Despite the fact that, for obvious reasons, they have lost their relevance, they have not been forgotten. The best proof of that is the current volume.

Jan Kowalczyk was mainly engaged in the study of the problems of the Neolithic period. Among other things, he dealt with the processes of Neolithisation, both the first and the second. His particular interest was the Funnel Beaker culture (TRB). But let us also remember that he also praised the importance of the theoretical considerations in archaeology, in times when hardly anyone took up such topics. The article from volume no. 29 of Wiadomości Archeologiczne (Kowalczyk 1963) stands in fact ahead of many "western" reflections of this type. Among other things, he proposes there the thesis that terminology, created in the early phase of science development, does not match realities; with increasing knowledge it even has a detrimental effect on further progress. Discussing the relationship between "archaeology" and "prehistory", he came to the conclusion - which should be dedicated to many contemporary researchers - that we cannot focus only on material artefacts. It is also necessary to study human (pre)history, and events related to it, also in the most remote epochs. For this reason, in place of the term "culture", he proposes the term "people" (e.g. "People of the funnel beakers"). Such an approach would actually mean that archaeological cultures, if diagnosed well, reflect real prehistoric entities (Kowalczyk 1963: 3). Finally, referring to the material evidence, he calls for the full use of its cognitive potential, through the use of "auxiliary sciences", but above all by taking into account all probable interpretations and their premises.

Similarly, the statements, contained in the 1969 publication, on archaeological culture and its derivatives as well as the nature of archaeological evidence (Kowalczyk I969: 6-9) are highly innovative, not only in the Polish context. The same can be said 
about attempts to define notions, such as: style, cultural group, culture, cycle, and belief community included in this publication (Kowalczyk 1969: 8-9) not to mention thoughts on the genesis of archaeological cultures (Kowalczyk 1969: I0).

Finally, in the same publication, he enters even the essence of the humanities (and even a section of the theory of cognition related to these sciences), of course, addressing his ideas mainly towards archaeology and prehistory. Namely, he draws attention to the presuppositional character of investigation activities and the far-reaching relativity of results and interpretations, which is most often forgotten during routine research (Kowalczyk 1969: 3, 14). These thoughts and postulates, which demonstrate how we should approach scientific research, in Polish conditions (but of course not only), were slightly revolutionary in the late I960s and early I970s, and they remain so largely to this day. In other words, the postulates that derive from them remain today far from being fulfilled. It is unfortunate that little has resulted from all of the theorizing of Jan Kowalczyk, both in the domestic and international context. Certainly, one of the reasons that prevented wider knowledge of this work was the language. The other was the "iron curtain", but probably the lack of much interest from the potential audience played a big part in it. Nevertheless the challenge was thrown out.

Another thing that we can learn from Jan Kowalczyk, which I have already mentioned, and which partly results from the ideas already pointed out, is the ability to formulate bold and risky hypotheses that are logical and acceptable in the light of the current state of knowledge, although difficult to document. Such a skill must undoubtedly be combined with a considerable dose of scientific and personal courage (they can attract criticism, even sharp and unpleasant - cf. e.g. Kozłowski 197I) and in response require a talent for accurate retorts (see e.g. Kowalczyk 197I). Despite the fact that such hypotheses turn out to be often inaccurate, they become an inspiration to investigations, search and reflections, which ultimately lead to a better understanding of a given part of prehistory.

The topic of this text is the TRB in the western part of the historical region of Lesser Poland (Małopolska; Figs I, 2). This territory comprises loess uplands and foothills situated north and south of the upper Vistula River respectively. The valley of the upper Vistula River itself is also a part of this territory, not to mention part of the Western Carpathians.

Jan Kowalczyk did not pay much attention to this territory in his studies on the TRB, but all the above mentioned reflections and postulates also refer, of course, to this place and time. As far as more detailed issues are concerned, it is undoubtedly worth noting that he strongly emphasized the specific status of the TRB (Kowalczyk 


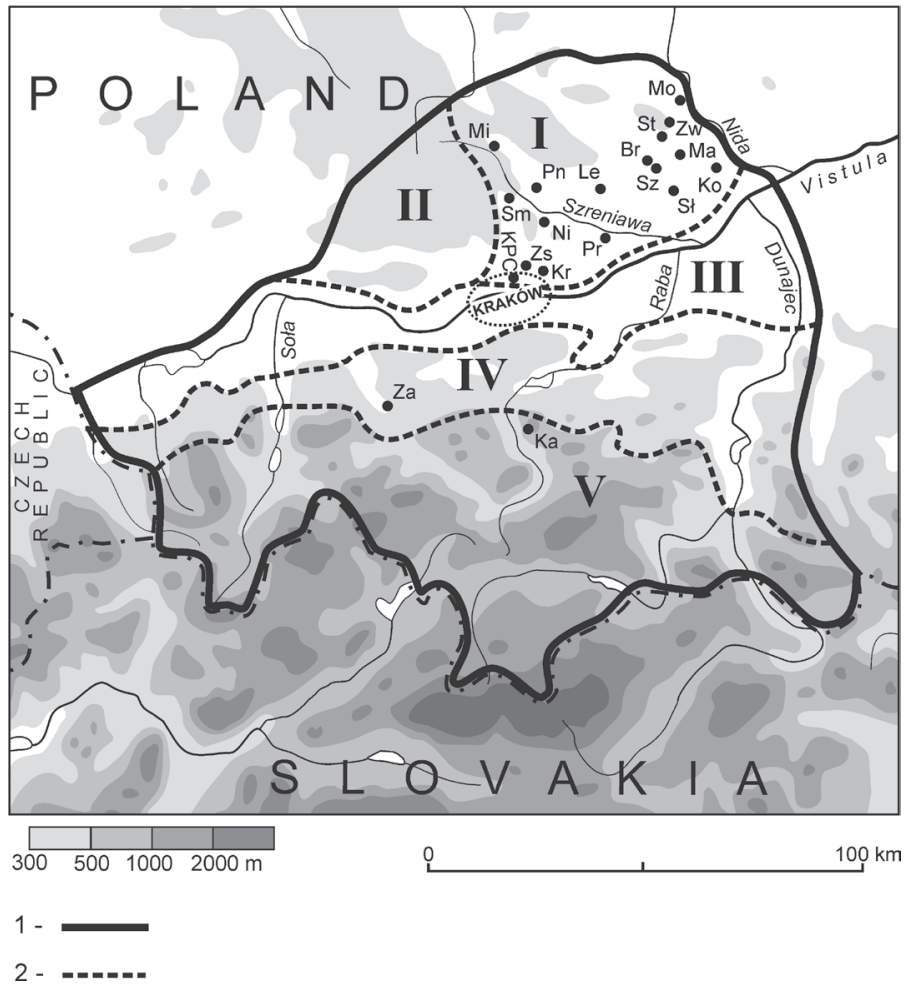

Fig. I. Territory of western Lesser Poland and neighbouring areas (based on Nowak 20I4: fig. I, with modifications); I - borders of the area discussed in the paper, 2 - borders of the basic ecological zones: I - "loess" upland (the most fertile zone), II - "jurassic" zone (part of the Cracow-Częstochowa Upland, with flint outcrops, in southern part covered with „loess” soils), III - zone of alluvial plains and basins, IV - belt of Carpathian foothills (in the region south and south-east of Cracow covered by "loess" soils and containing salt water springs), $\mathrm{V}$ - the Carpathian Mountains proper; Archaeological sites mentioned in the text and figures: $\mathrm{Br}-$ Bronocice, $\mathrm{Ka}$ - Kamiennik, $\mathrm{Kr}$ - Karniów, Ko - Kolosy, KPC - Kraków-Prądnik Czerwony, Le - Lelowice, Ma- Malżyce, Mi - Miechów, Mo - Mozgawa, $\mathrm{Ni}$ - Niedźwiedź, Pn - Prandocin, Pr - Proszowice, Sł - Słonowice, Sm - Smroków, St - Stradów, Sz - Szarbia, Za - Zagórze, Zs - Zastów, Zw - Zawarża.

I969; 1970), which in fact was also an early precedent of later (and indeed current) views. Namely, for the most part the TRB is a reflection of a pottery style, i.e. pottery is the basic, or perhaps the only element determining and unifying "the style of Funnel Beakers" (Kowalczyk 1969: 35). Such an approach is still acceptable these days. It also has its consequences for considerations on other aspects of the TRB, e.g. its genesis. If the TRB is essentially a ceramic style, then it is justified to consider its genesis in 


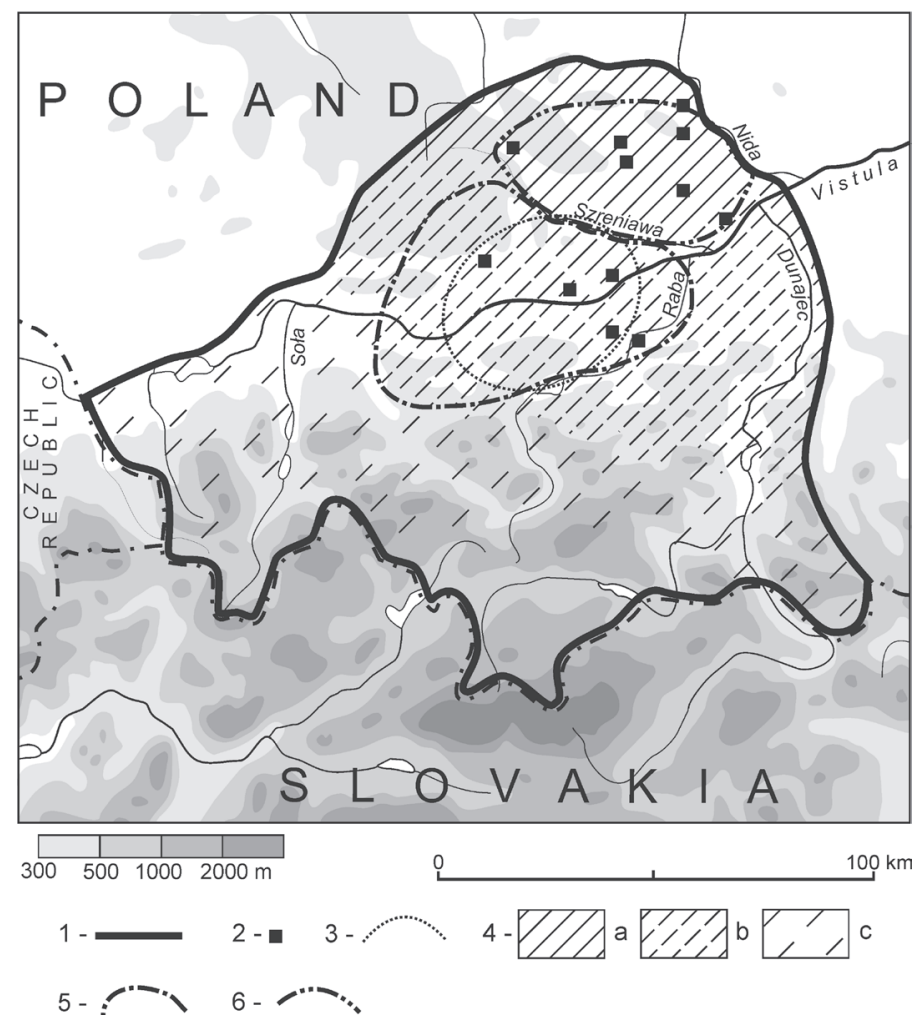

Fig. 2. Territory of western Lesser Poland and the main archaeological units in the late 5 th, $4^{\text {th }}$ and early 3rd millennia BC (based on Nowak 2or4: fig. 2, with modifications);

I - borders of the area discussed in the paper, 2 - sites of the Lublin-Volhynian culture,

3 - the Wyciąże-Złotniki group, 4 - the Funnel Beaker culture (a - dense settlement typical of "loess" upland, $\mathrm{b}$ - more dispersed settlement typical of foothill, alluvial plains/basins and "jurassic" zones, c - highly dispersed settlement typical mainly of mountainous zone), 5- the Baden culture, 6 - the Beaker/Baden assemblages.

two ways: generally and regionally/locally. Such approaches can be found in current literature (e.g. Czerniak 20I8).

Since the publications by L. Kozłowski in the I920s, sites and materials of the TRB in this area have been included into a territorial unit separated from the Lowland groupings of this culture, be it the Lesser Poland culture (Kozłowski 1924), the 
Southern Group (Jażdżewski 1936; Kostrzewski et al. 1965), or the South-Eastern Group (Wiślański 1979; Kadrow 2018). Jan Kowalczyk in his text in The Neolithic in Poland (1970) applies the territorial division into four groups (modo Jażdżewski), including the Southern Group, but emphasizes that it is insufficient and we should operate with smaller units (Kowalczyk 1970: 163-164).

Traditionally, for many years, knowledge on the TRB in western Lesser Poland has been quite modest, especially in the interpretative sphere, despite the fact that some of the earliest TRB findings in Lesser Poland (e.g. Wawrzeniecki I898; 1900; cf. also Cabalska 1960: 159, 218; Rook 1980) came from this area (Fig. 3). This was not changed by numerous excavations in the I950s and I960s, to name just Miechów (Mycielska, Wałowy 1964), Prandocin (Radwański 1957), Lelowice (Burchard 1964; 1966), Niedźwiedź (Burchard 1968), Zawarża (e.g. Kulczycka 196r; Kulczycka-Leciejewiczowa 1965), or Stradów (Gromnicki 196I). The large-scale rescue investigations in Kraków-Nowa Huta also led to the discovery of a considerable amount of TRB material, although in comparison with other Neolithic cultures it was a less significant amount (cf. Godłowska 1976). As a result of the lack of comprehensive publications of these field investigations, western Lesser Poland was treated as an area rather bypassed by the TRB communities, due to, among other things, intensive and long-lasting Lengyel-Polgár settlement.

This situation has changed since the late 1960s and early I970s, when the results of systematic surface surveys on "western loess uplands" were published (Kruk 1969; 1970; Rydzewski 1972; 1973; cf. also Liguzińska-Kruk 1981; Burchard 1997). Among other things, these activities were crowned by a groundbreaking monograph on Neolithic settlement in this region by J. Kruk (1973). These activities provided a huge load of data on the culture in question. It can be said without great exaggeration that, from the TRB perspective, the north-eastern part of western Lesser Poland has now become the area best studied and distinguished in quantitative terms in a nationwide scale. This was fully confirmed by later research conducted within the AZP (Archeologiczne Zdjęcie Polski - "Archaeological Record of Poland") project (see e.g. Nowak 200I). The intensive, large-scale, interdisciplinary excavations at the large TRB site of Bronocice (Hensel and Milisauskas 1985: 52-77) in the I970s was also of unprecedented significance for the topic under consideration. The results, so far published (e.g., Kruk and Milisauskas 20I8; Kruk et al. 20I8; see further references in both monographs), provided fundamental data on the settlement, economic and material patterns of the TRB community that lived in loess upland landscape. Not to be overlooked are the equally fundamental determinants of absolute and relative chronology, the importance of which goes far beyond the site at Bronocice and sites of the TRB in its immediate vicinity. In fact, the Bronocice chronological scheme has become a kind of model of the general developmental pattern of the TRB in the whole upper Vistula River basin. 

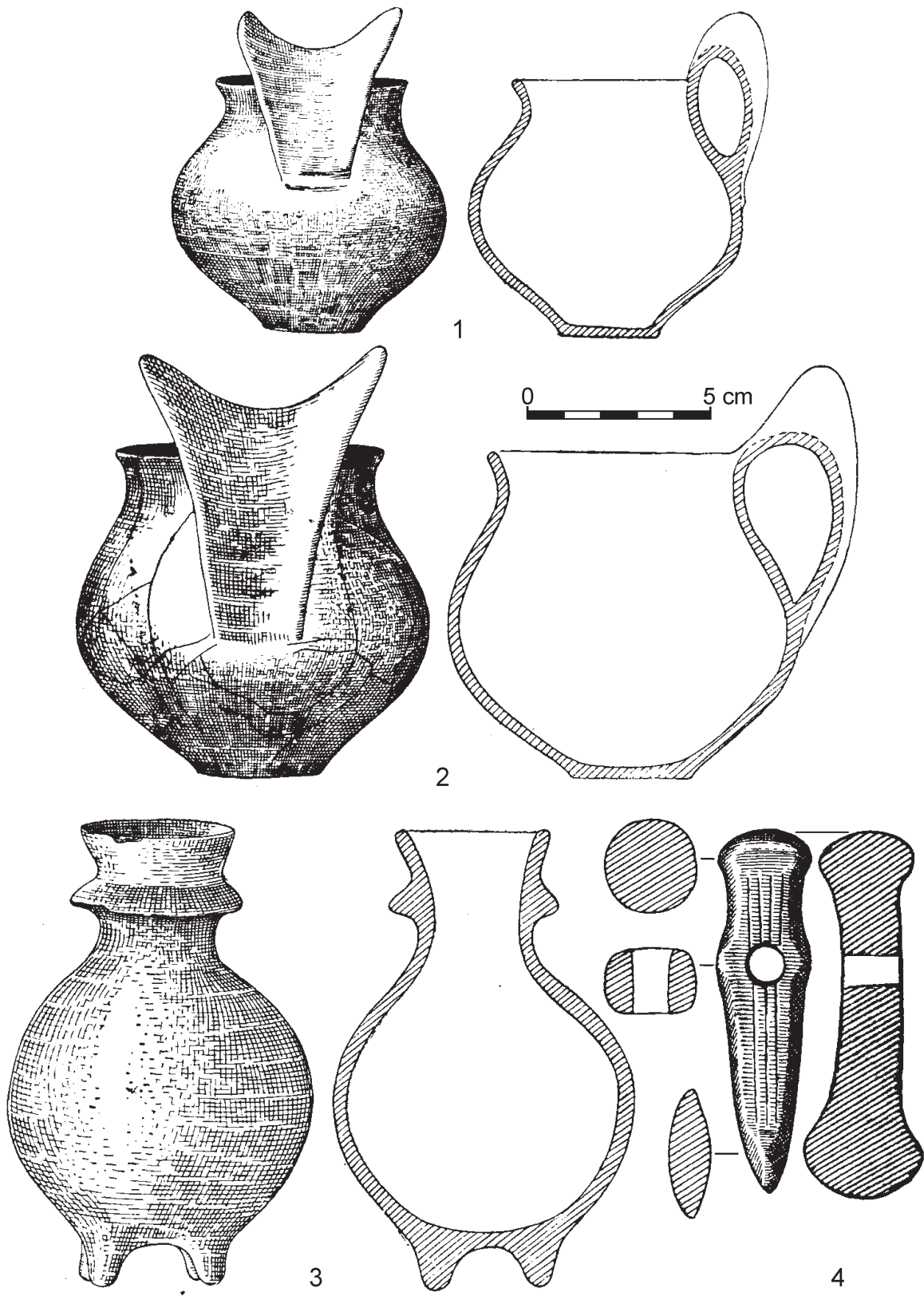

Fig. 3. Selected pottery of the Funnel Beaker culture: $\mathrm{I}-$ Karniów, single ansa lunata cup found in $\mathrm{I} 858$, 2-4 - Zastów, ansa lunata cup (2), collared flask (3), button-butted axe (4), possibly from a grave, found in 1885 (after Cabalska 1960). 
In the last two decades of the 2oth century, in addition to the continuation of the AZP action, several other research projects are adding to our understanding of the western Lesser Poland TRB. Of particular importance were excavations of the sepulchral complex in Słonowice (in practice, continued until now - see Tunia 1990; 2006; Przybyła and Tunia 2013) and research on the Neolithic in the Carpathian zone. The monograph by P. Valde-Nowak (1988) can be considered the culmination of the initial stage of the latter studies. It made possible the identification of a number of finds of the TRB, mainly single ones, also in the Western Lesser Poland part of this zone, which clearly shifted the range of this culture towards the south. Equally important is the monograph by E. Rook (1980) on the Neolithic settlement in the caves of the Cracow-Częstochowa Upland, which has systematized our information on the local TRB.

Since the end of the 2oth century, a major role in providing new archaeological data in Poland has been taken over by the rescue investigations carried out in connection with large road investments. It is no different in western Lesser Poland. Particularly important here were the excavations on the $\mathrm{A}_{4}$ motorway route, the results of which are being systematically published by the Cracow Team for Motorway Research, although unfortunately much still remains to be done. As far as the TRB is concerned, these studies have perhaps produced less spectacular results, especially in comparison with the "southern" Neolithic cultures, but the volume of new data is substantial (e.g. Zastawny et al. 20II; Zastawny 20I4; Nowak and Rodak 20I5). In the last few years, there have also been conducted rescue investigations to the north of Cracow (including the northern beltway of the city and the $S_{7}$ road). The first reports, so far oral, indicate relatively abundant findings of the TRB, perhaps even quantitatively ahead of those from the $\mathrm{A}_{4}$ motorway. Finally, it is also worth mentioning the purely scientific excavation of another large TRB settlement in Mozgawa, which was carried out in 2014-2016 (see Nowak 2017; Nowak et al. 2017; Korczyńska et al. 2019). The results are not yet published and the work here will be continued.

Discussing the research achievements of recent years, it is undoubtedly worth noting the somewhat unexpected absolute datings, indicating the ties with the TRB of at least a few kurgan graves (Kolosy, Malżyce - Włodarczak 2008a; Jarosz et al. 2009; Tunia and Włodarczak 20II; Jarosz et al. 2013), which originally seemed to belong to the Corded Ware culture. This broadens the already considerable spectrum of sepulchral behaviors of the Western Lesser Poland communities of the TRB.

Currently it is very well known that western Lesser Poland treated globally is a very important centre of the TRB. Its sites are so numerous that it would be difficult to 
count them at the moment. Their number is clearly higher than the number of sites of the "Danubian" Neolithic. This is demonstrated, for instance, by data from the Bronocice micro-region, where the number of the TRB sites is at least three times higher (Milisauskas and Kruk 1984; 1989; Kruk et al. 1996: 28-32). The literal interpolation of the available data from this micro-region, referring to the zone of loess uplands north of the Vistula River only, suggests that the number of sites in this zone should exceed Iooo.

The communities who left material relics referred to as the TRB were characterised by varied patterns of settlement and economic behaviours (Fig. 2). The "first" pattern is represented by "dense" settlement in the loess upland of western Lesser Poland. The TRB sites are much more evenly distributed than those attributed to the Linear Band Pottery culture (LBK) and the Lengyel-Polgár complex (Kruk et al. 1996: 26-33). This also means that large number of the TRB sites appear in zones previously avoided by "Danubian" groups, mainly on the margins of river valleys and in upland watershed areas (Kruk 1980: I08-II8). In brief, one can notice a tendency to fill the landscape. The discussed zone is distinguished by the highest formal differentiation of the Funnel Beaker sites, which can be divided into camps, small, medium-size and large settlements (Kruk and Milisauskas 1999). Finally, there are sepulchral sites, including both flat cemeteries and monumental complexes. According to Kruk and Milisauskas (1999; cf. also Milisauskas and Kruk 1984; 1989) around the mid-4th century, micro-regional settlement complexes clustered around large, central settlements.

It seems that TRB people living in this zone practised what may be described as shifting slash-and-burn farming. This locally led to the considerable deforestation of the landscape. The process became more intensive after the mid-4th millennium BC, which produced even larger areas devoid of forest (Kruk et al. 1996: 69; Michno 2004: 58-69; Szwarczewski 2009; Poręba et al. 20I2; Moskal-del Hoyo et al. 2018). However, it is impossible to determine whether all of the discussed area was covered by grass or parkland formations at the end of the 4th millennium BC and in the early 3rd millennium BC. One way or another, the TRB communities exploited a much greater part of the available landscape than the preceding groups of the LBK and Lengyel-Polgár people.

The "second" pattern of the TRB settlement is characteristic of the Carpathian foothills, northern fringes of the mountains proper and the eastern part of the zone of alluvial plains and basins (Nowak 20I4). The settlement is clearly more scattered here. The archaeological record within sites is manifested by isolated finds or small concentrations of artefacts and features, which provisionally can be classified as either small settlements or camps, and only rarely as medium-size settlements. In this context, one should also mention the finds from the southern part of the Cracow-Częstochowa Upland, which may be the remains of a system of flint resource exploitation. Subsistence was based on farming and animal breeding, although they were realised in 
a manner which did not lead to any considerable environmental transformations (e.g. Nalepka 2003; Nalepka et al. 2005: I05-106).

The mountain areas of the West Carpathians were occasionally infiltrated, which was connected with herding (perhaps seasonal) and (or maybe primarily) hunting. The longer stays of small groups of people who locally engaged in small-scale farming can also be taken into account (Margielewski et al. 20IOa; 20Iob; 20II; Nowak 20I4).

As to the dawn of the TRB in western Lesser Poland, the combination of all the available data and Bayesian modelling of all radiocarbon dates indicate that date c. $3750 / 3700 \mathrm{BC}$ should be regarded as marking the most likely beginning of the process of its formation (Fig. 4; cf. also Nowak 20I7). The ceramic typology does not exclude this possibility (Nowak 2009: 334-336, see further references), although this date is later than the commonly suggested date of 3950/3900/3800 BC (Włodarczak 2006; Kruk et al. 20I6; Milisauskas et al. 20I6; Kruk and Milisauskas 20I8; Kruk et al. 20I8). It has to be emphasised that the latter proposals has been based only on single date from the area under discussion (Bronocice) and - comparatively - other areas in Lesser Poland (Gnojno - Nowak 2006; Skołoszów - Rybicka et al. 2017), whose reliability can be challenged. The date of $c .3750 / 3700 \mathrm{BC}$ does not contradict the stratigraphic relations between the Lublin-Volhynian culture and the TRB recorded at Bronocice because the general chronology of the Lublin-Volhynian culture in western Lesser Poland can be situated in $c$. 3900-3700/3600 BC (Nowak 2017; for a different opinion: Kruk et al. 2018: 36-38).

Around $3750 / 3700 \mathrm{BC}$, there were only several/a dozen or so "founding" sites of TRB in western Lesser Poland. In the period of $3750 / 3700-3500$ BC this number should be still evaluated as rather low, but with increasing tendency. This could be so, since it seems possible that the late Lengyel-Polgár groups functioned in western Lesser Poland until the mid-4th millennium BC.

It is not possible, mainly due to lack of DNA data, to determine whether the origins of the local TRB were associated with some migrations (i.e. from either the Eastern Group of TRB or some areas in the upper Vistula Basin settled by TRB people before $3750 / 3700 \mathrm{BC}$ ) or with transformations of late Lengyel-Polgár cultural model. However, a relatively long period of postulated coexistence (at least 200 years) would suggest with a slightly higher probability the latter option. Some similarities in material culture (but - admittedly - of the second rank - Nowak 2004) could support such an idea (see also Kozłowski and Nowak 2018). Certainly, coeval external migrations and local cultural transformations cannot also be excluded as well as many possible mechanisms in between these two extreme processes. 
Assemblages of the Modlnica type (Zastawny and Grabowska 20II), with pottery decorated with needle etching ornament (Furchenstichkeramik), most probably also mark a minor migration from the south-west (Moravia?) between ca. 3900 and ca. $3600 \mathrm{BC}$, to make the situation in the first half of the 4th millennium BC more complicated. Interestingly, this migration brought mixed pottery, consisting of Baalberge, epi-Lengyel and Hunyadihálom elements. Perhaps, this phenomenon accelerated the local transformation of the late Lengyel-Polgár culture into the TRB.

The time frame of $c .3500-3300 \mathrm{BC}$ should be considered the heyday of the TRB in western Lesser Poland (Fig. 5). The majority of the hundreds or perhaps thousands of TRB sites should be referred to that time. It was then that the Neolithic settlement became evenly dispersed in the landscape, including topographical and ecological zones previously avoided by the "Danubians". On the other hand, it seems quite possible that in this period existed small groups of the Lengyel-Polgár culture origins that did not undergo "Funnel Beaker" acculturation, and started to accept some Transcarpathian, i.e. (mainly) Baden patterns. Such Baden patterns were accepted by some TRB groups as well (Zastawny 2018).

Until about $3300 \mathrm{BC}$, there was a small but growing occurrence of these patterns, but after that date they relatively quickly gained in importance. Their participation in pottery stylistics becomes so important that the TRB proper disappears from archaeological perspective. As a consequence, archaeologists felt obliged to discern a syncretic entity labelled "Beaker/Baden Assemblages" (B/BA) (Figs 6, 7). It should be emphasised that these Baden features are of archaic characteristics. They were known and used a bit before the aforementioned date $3300 \mathrm{BC}$. They must have been somehow preserved, i.e. through cutting the previous interactions with the Baden world.

The mechanisms behind these processes remain unclear, and a number of potential explanations can be proposed. Among the most convincing explanations is the simplest one, which posits that they were connected with a kind of "fashion" for the Baden culture. Baden elements, including pottery, became attractive and prestigious, and by virtue of their southern or south-western origin started to play the role of symbols of the leading civilisation centre of that period situated in the Balkans and Carpathian Basin.

Thus, the discussed process of western Lesser Poland "Badenisation" was of the internal nature, and consisted of the cultural development, perhaps accelerated since c. 3100 BC in the face of the Baden "invasion" (see below). Perhaps, it is no coincidence that the $\mathrm{B} / \mathrm{BA}$ seems to concentrate in large settlements, most probably fortified (Kruk and Milisauskas 1999; Zastawny 2008), and the number of its sites seems to decrease when compared to "classic" TRB.

The B/BA discussed here occurs basically in the area of the eastern part of western Lesser Poland loess uplands. In the western part of the area under consideration, the Baden culture appeared $c .3100 \mathrm{BC}$ (cf. Zastawny 20I5b). Admittedly, this date is later 


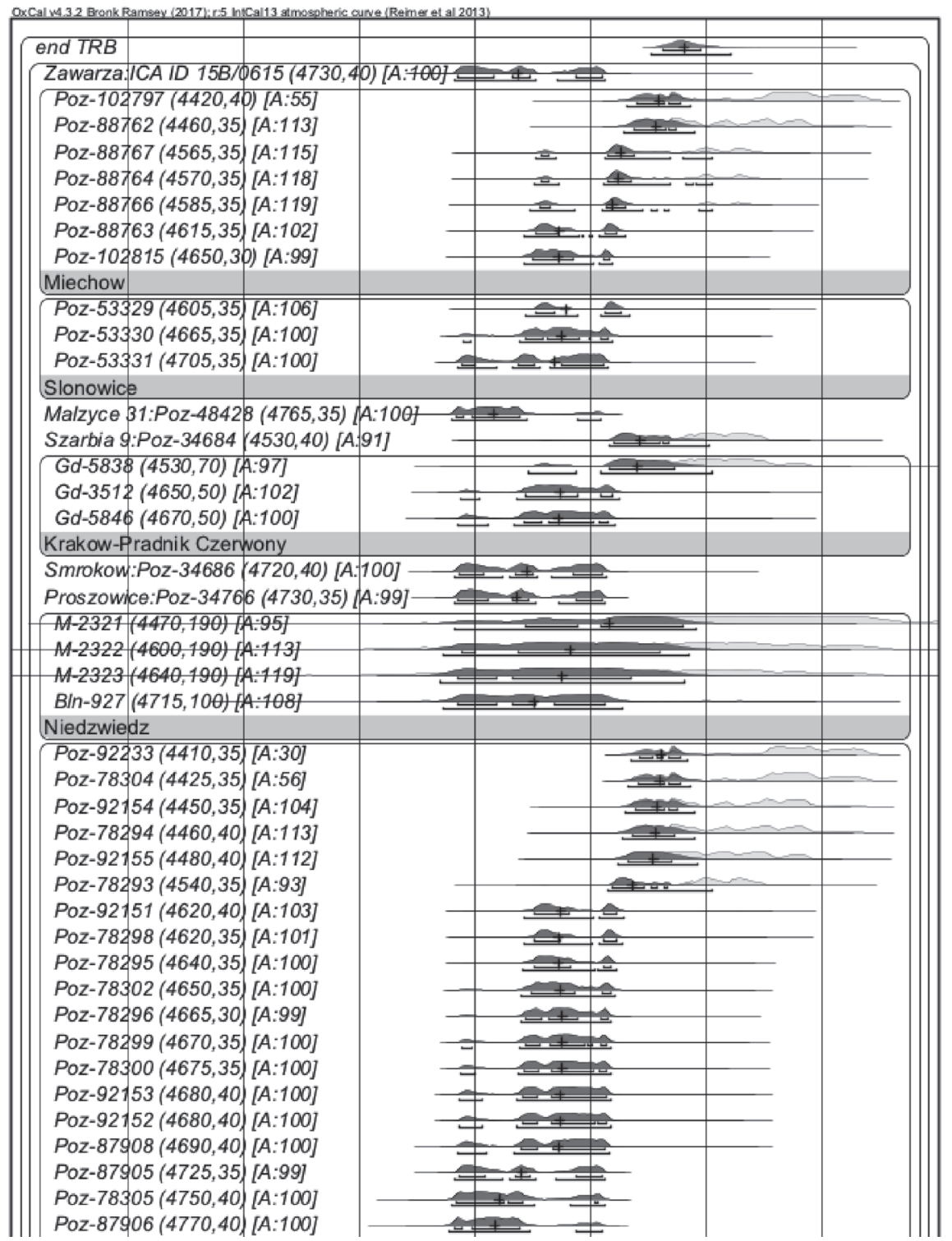

Fig. 4a. Bayesian modelling of radiocarbon dates of the Funnel Beaker culture; see references in Nowak 2017 and Kruk et al. 20I8; part of dates from Mozgawa and all dates from Miechów have not been published so far; calibrations and modelling by the OxCal 4.3.2 package (Bronk Ramsey 2009; Reimer et al. 2013; Bronk Ramsey 2017). 


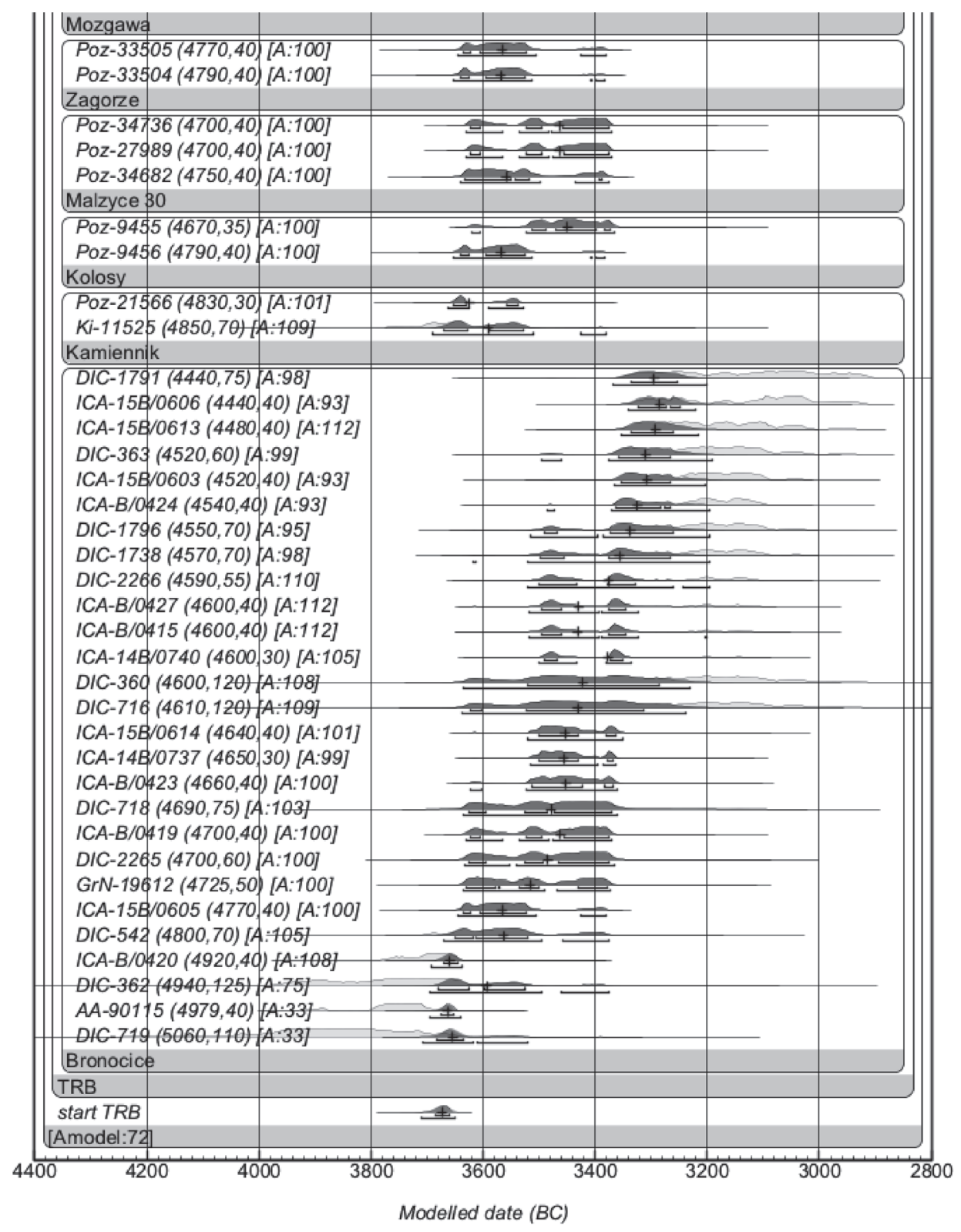

Fig. 4b. Bayesian modelling of radiocarbon dates of the Funnel Beaker culture (continued). 

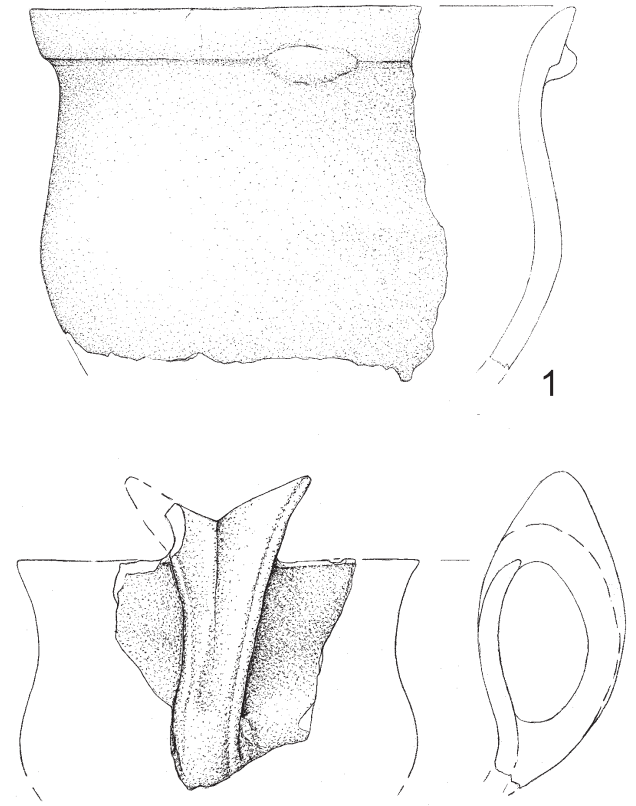

3
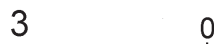

0

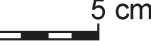

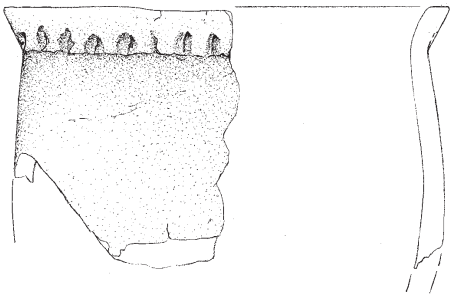

2

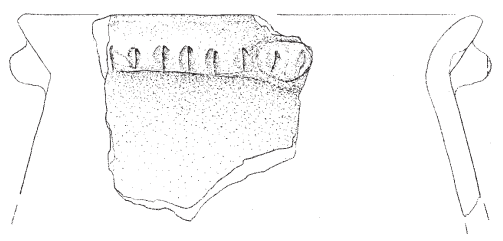

4
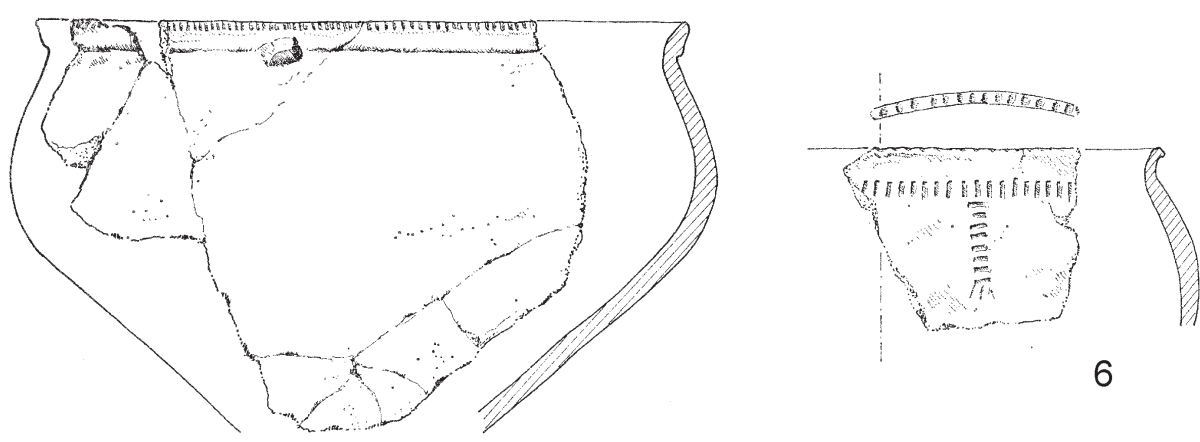

6

5

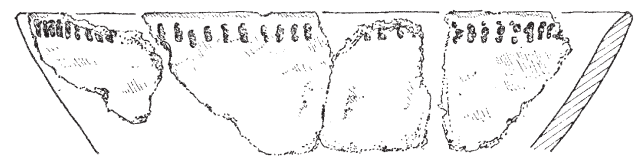

7

Fig. 5. Selected pottery of the Funnel Beaker culture: $\mathrm{I}-4$ - Mozgawa (unpublished, drawn by M. Korczyńska); 5-7 - Kraków-Prądnik Czerwony (after Rook and Nowak 1993). 


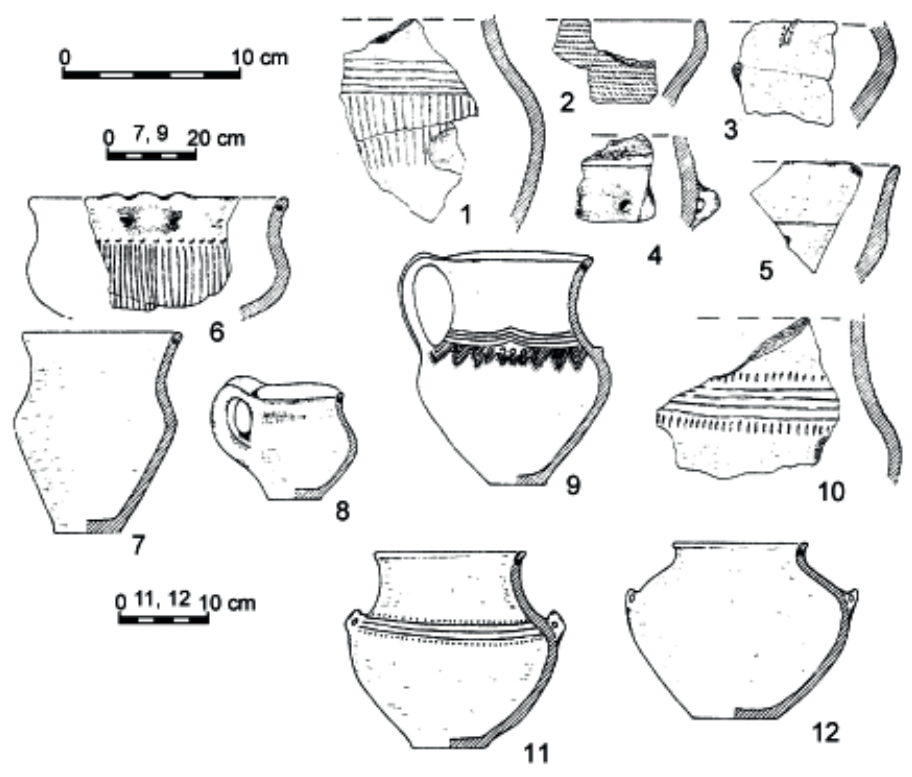

Fig. 6. Selected pottery of the Beaker/Baden assemblages at Bronocice: I-IO - feature 2-B2, II-I2 - feature I-A5 (after Kruk and Milisauskas I990).

than could be expected before obtaining large series of ${ }_{14} \mathrm{C}$ dates in recent years. However, these highly reliable datings indicate precisely this and no other situation. Besides, the proposed time interval does not contradict the overall principles of typological development and currently understood patterns of the absolute chronology of the Baden phenomena (Horvath and Svingor 20I5; Zastawny 2008; 20II; 20I5a).

These relatively late beginnings convincingly confirm what we had long suspected, namely that the Baden culture proper in western Lesser Poland appeared as the effect of rapid (a single wave?) migration from behind the Carpathians. This migration was executed by groups of people coming from its late classic stage. Consequently, those people brought here the model of the developed Baden culture, in all its aspects. They settled down in a small area within and around Cracow.

The lack of any TRB elements in materials of the Baden culture proper is particularly pregnant with meaning. Certainly, it corroborates the migration scenario, but also directly suggests that the TRB communities in the western part of the area under consideration could have been expelled or exterminated. A fairly sharp geographical boundary between the areas of the Baden culture and B/BA (Fig. I; see Zastawny 2008: fig. 2; but cf. a bit different opinion in Włodarczak 2008b: 252) could also support an interpretation of this kind. 
However, we have to admit that we do not possess any knowledge on the "cultural situation" in the western part of the territory under discussion (i.e. the Cracow agglomeration and surrounding areas) between $c .3300$ and $c .3100 \mathrm{BC}$. There are neither TRB nor $\mathrm{B} / \mathrm{BA}$ sites there with dates later than $c .3300 \mathrm{BC}$. Currently, two speculative hypotheses can be put forward to explain this: i) there were some groups with material culture of the B/BA type, unrecognised so far, ii) there were some earlier Baden groups, equally unidentified as yet (some finds of Baden pottery made during rescue works executed in Kraków-Nowa Huta in 2017 could tentatively support the latter option; information from J. Bober and A. Zastawny). The quantitative dimensions of the Niedźwiedź/Wyciąże materials (at least in the present state of research, cf. e.g. Nowak 20I7; Zastawny 20I8) seem to be too modest to represent this period, not to mention problems with its absolute and relative chronology. Similarly, the question of the existence of the TRB proper (i.e. non-Badenised), simultaneously with the B/BA and Baden culture remains open.

Little is also known about cultural situation in the mountain zone of SW Poland during the development of the Baden culture and $\mathrm{B} / \mathrm{BA}$. Was it still occupied by the TRB and/or the Baden culture groups? In the case of the latter, such a possibility is made obviously more likely by the fact that the Baden culture enclave in western Lesser Poland maintained contact with the core areas. However, there is no direct proof for such a conclusion.

The cause of the sudden disappearance of the $\mathrm{B} / \mathrm{BA}$ as well as Baden culture around 2800 BC remains unclear. Results of performed Bayesian modelling of ${ }_{14} \mathrm{C}$ dates (Nowak 2017; cf. also Fig. 7) suggest either the occurrence of a hiatus between this disappearance and the origins of the Corded Ware culture, or the political/historical nature of this archaeological change. In the latter case it would be a complex of events that included the removal and/or elimination of the B/BA communities by "Corded" communities, which represented a radically different type of culture. Perhaps these communities had moved to the region from the east (e.g. Allentoft et al. 20I5).

It turns out that in western Lesser Poland, the Funnel Beaker culture was perhaps never the only cultural unit. Even if such a situation was the case, it was limited to a relatively short period, of about 200 years, roughly in the mid-4th millennium BC (ca. 3550-3350 BC). How can this situation be interpreted from an anthropological and historical perspective? We believe that until the arrival of the Baden population around $3100 \mathrm{BC}$, this territory was occupied by the TRB populations, which genetically originated from the Lengyel-Polgár culture communities, but adopted and adapted new material culture (mainly pottery) and new patterns of settlement, subsistence, 


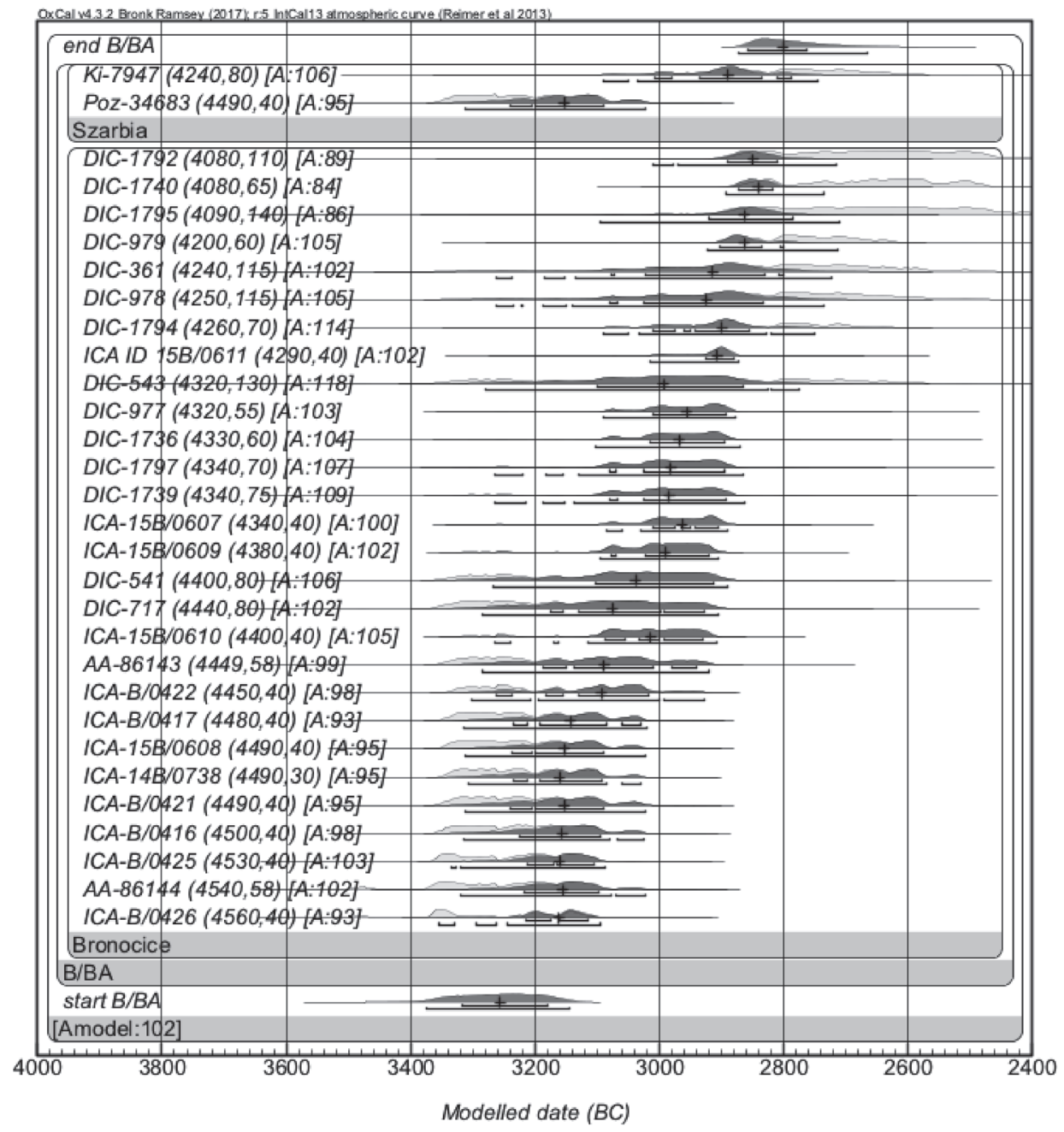

Fig. 7. Bayesian modelling of radiocarbon dates of the Beaker/Baden assemblages; see references in Nowak 2017 and Kruk et al. 2018; calibrations and modelling by the OxCal 4.3.2 package (Bronk Ramsey 2009; Reimer et al. 2013; Bronk Ramsey 2017).

ideology and - possibly - social structures. Processes of this kind were, however, varied in intensity. Therefore, the norm was a mixed situation in which one part of the local population used new patterns of material culture (and not only), while the other part preserved the old patterns. Certainly, the influx of "new" outsiders cannot be ruled out, but the "old" genetic pool predominated until beginning of the 3ist century BC and in many places probably until $2800 \mathrm{BC}$. Interestingly, these Lengyel-Polgár turned 
TRB populations were apparently still willing to adopt new cultural patterns. It is possible that their end around $2800 \mathrm{BC}$ was also caused by political events, connected with the infiltration and expansion of Corded Ware culture groups.

The scenarios we have proposed above, particularly those referring to the appearance of the Baden culture proper and Corded Ware culture, may appear naïve, and surely out of fashion. They often assume an important role for political events and human agency rather than cultural transformations. What is more, they often regard some archaeological units as reflections of phenomena of political and - broadly speaking - historical dimension. Nevertheless, we believe that for this particular time and place they are just as probable as any other. If we look at historic times, described in written sources, it becomes clear that events of a political character as well as conscious human activity often influence, and sometimes even shape the history of humankind. Such interpretations are a rightful element of the set of tools to describe and explain this history.

\section{ACKNOWLEDGEMENTS}

Acknowledgements are due to grants of the National Science Centre of Poland: 2013/II/B/HS3/03822 (Head: Magdalena Moskal-del Hoyo), 2013/ro/M/HS3/o0537 (Head: Aldona Mueller-Bieniek) and 2016/23/B/HS $3 / 00387$ (Head: Marek Nowak) for financial support of radiocarbon dating of the sites at Mozgawa and Miechów.

Translated by author

\section{REFERENCES}

Allentoft, M. E., Sikora, M. and Sjögren, K.-G. et al. 2015. Population genomics of Bronze Age Eurasia. Nature 522: 167-172. doi: I0.1038/natureI4507

Bronk Ramsey, Ch. 2009. Bayesian analysis of radiocarbon dates. Radiocarbon 51: 337-360. doi: Io.IOI7/ soo33822200033865

Bronk Ramsey, Ch. 2017. OxCal 4.3 Manual. Electronic document, https://cı4.arch.ox.ac.uk/oxcal/OxCal. html, accessed April 2019 .

Burchard, B. 1964. Sprawozdanie z wstępnych badań archeologicznych kultury czasz lejowatych w Lelowicach, pow. Proszowice w 1962 r. Sprawozdania Archeologiczne 16: 44-46.

Burchard, B. 1966. Sprawozdanie z poszukiwań osady kultury czasz lejowatych w Lelowicach pow. Proszowice w latach 1963-64. Sprawozdania Archeologiczne 18: 46-50.

Burchard, B. 1968. Sprawozdanie z wstępnych badań archeologicznych osady kultury czasz lejowatych w Niedźwiedziu, pow. Miechów, w 1965 roku. Sprawozdania Archeologiczne 19: 37-40.

Burchard, B. 1997. Kultura pucharów lejkowatych. In K. Tunia (ed.), Z Archeologii Matopolski. Historia i stan badań zachodniomatopolskiej wyżyny lessowej, I23-I46. Kraków. 
Cabalska, M. 1960. Kultura pucharów lejkowatych. Prace Archeologiczne I, Pradzieje Powiatu Krakowskiego, tom I: $143-234$.

Czerniak, L. 20I8. The emergence of TRB communities in Pomerania. Prace i Materiaty Muzeum Archeologicznego i Etnograficznego w Eodzi. Seria Archeologiczna 47 (2016-2017): 103-130.

Godłowska, M. 1976. Próba rekonstrukcji rozwoju osadnictwa neolitycznego w rejonie Nowej Huty. Materiaty Archeologiczne Nowej Huty 5: 7-178.

Gromnicki, J. I96r. Grób kultury czasz lejowatych w Stradowie, pow. Kazimierza Wielka. Sprawozdania Archeologiczne 13: II-I6.

Horváth, T. and Svingor, É. 2IO5. The spatial and chronological distribution of the so-called "Baden Culture". In M. Nowak and A. Zastawny (eds), The Baden Culture Around the Western Carpathians, I9-74. Kraków.

Hensel, W. and Milisauskas, S. 1985. Excavations of Neolithic and Early Bronze Age Sites in South-Eastern Poland. Wrocław-Warszawa-Kraków-Gdańsk-Łódź.

Jarosz, P., Tunia, K. and Włodarczak, P. 2009. Burial mound No. 2 in Malżyce, the district of Kazimierza Wielka. Sprawozdania Archeologiczne 6r: 175-23I.

Jarosz, P., Szczepanek, A. and Włodarczak, P. 2013. Tomb no. I at Malżyce, site 3I (distr. Kazimierza Wielka) and the megalithic Funnel Beaker cemeteries in the loess region of western Małopolska. Sprawozdania Archeologiczne 65: 293-309.

Jażdżewski, K. 1936. Kultura puharów lejkowatych w Polsce zachodniej i środkowej. Poznań.

Kadrow, S. 2018. South-eastern group of Funnel Beaker culture. Prace i Materiaty Muzeum Archeologicznego i Etnograficznego w Eodzi. Seria Archeologiczna 47 (2016-2017): 103-130.

Korczyńska, M., Cappenberg, K., Nowak, M., Szwarczewski, P. and Moskal-del Hoyo, M. 2019. Multi-methodological approaches to investigate large archaeological sites: The case study of the Eneolithic settlement in Mozgawa, western Lesser Poland. Journal of Archaeological Science: Reports 27 , IOI94I. doi: I0.IOI6/j.jasrep.2019.IOI94I

Kostrzewski, J., Chmielewski, W. and Jażdżewski, K. 1965. Pradzieje Polski, wyd. II. Wrocław-WarszawaKraków.

Kowalczyk, J. 1963. Terminologiczne konsekwencje. Wiadomości Archeologiczne 29: I-8.

Kowalczyk, J. 1969. Początki neolitu na ziemiach polskich. Wiadomości Archeologiczne 34(I): 3-69.

Kowalczyk, J. 1970. The Funnel Beaker Culture. In T. Wiślański (ed.), The Neolithic in Poland, 144-I77. Wrocław-Warszawa-Kraków.

Kowalczyk, J. 197I. W związku z dyskusją nad początkami neolitu. Wiadomości Archeologiczne 36: 243-252.

Kozłowski, J. K. 197I. W sprawie początków neolitu na ziemiach polskich. Wiadomości Archeologiczne 36: 44-50.

Kozłowski, L. 1924. Mtodsza epoka kamienna w Polsce (Neolit). Lwów.

Kozłowski, S. K. and Nowak, M. 2018. Funnel Beaker origins in Polish territories. Prace i Materiaty Muzeum Archeologicznego i Etnograficznego w Eodzi. Seria Archeologiczna 47 (2016-2017): 289-308.

Kruk, J. 1969. Badania poszukiwawcze i weryfikacyjne w dorzeczu Dłubni. Sprawozdania Archeologiczne 21: $346-373$.

Kruk, J. 1970. Badania poszukiwawcze i weryfikacyjne w górnym i środkowym dorzeczu Szreniawy. Sprawozdania Archeologiczne 22: 271-294.

Kruk, J. 1973. Studia osadnicze nad neolitem wyżyn lessowych. Wrocław-Warszawa-Kraków-Gdańsk.

Kruk, J. I980. Gospodarka w Polsce potudniowo-wschodniej w V-III tysiacleciu p.n.e. Wrocław-WarszawaKraków-Gdańsk. 
Kruk, J. and Milisauskas, S. 1990. Radiocarbon dating of Neolithic assemblages from Bronocice. Przegląd Archeologiczny 37: 195-234.

Kruk, J. and Milisauskas, S. 1999. Rozkwit i upadek spoteczeństw rolniczych neolitul The Rise and Fall of Neolithic Societies. Kraków.

Kruk, J. and Milisauskas, S. 20I8. Bronocice. The Chronology and Development of a Neolithic Settlement of the Fourth Millennium BC. Kraków.

Kruk, J., Lityńska-Zając, M. and Milisauskas, S. 2016. Gospodarka roślinna w neolicie. Studium przypadku / Neolithic plant cultivation at Bronocice. Kraków.

Kruk, J., Milisauskas, S., Alexandrowicz, S. W. and Śnieszko, Z. 1996. Osadnictwo i zmiany środowiska naturalnego wyżyn lessowych. Kraków.

Kruk, J., Milisauskas, S. and Włodarczak, P. 2018. Real Time. Radiocarbon Dates and Bayesian Analysis of the Neolithic Settlement at Bronocice, Fourth Millennium BC. Kraków.

Kulczycka, A. 196r. Sprawozdanie ze wstępnych badań archeologicznych na terenie osady kultury czasz lejowatych w Zawarży, pow. Pińczów. Sprawozdania Archeologiczne 13: 17-22.

Kulczycka-Leciejewiczowa, A. 1965. Sprawozdanie z badań osady kultury czasz lejowatych w Zawarży, pow. Pińczów w 1963 roku. Sprawozdania Archeologiczne 17: 65-75.

Liguzińska-Kruk, Z. 198I. Poszukiwania archeologiczne w dorzeczu górnej Nidzicy. Sprawozdania Archeologiczne 33: I9I-2I4.

Margielewski, W., Krąpiec, M., Valde-Nowak, P. and Zernitskaya, V. 20ı0a. A Neolithic yew bow in the Polish Carpathians. Evidence of the impact of human activity on mountainous palaeoenvironment from the Kamiennik landslide peat bog. Catena 80: I4I-I53.

Margielewski, W., Michczyński, A. and Obidowicz, A. 2oıob. Records of the middle - and late Holocene palaeoenvironmental changes in the Pcim-Sucha landslide peat bogs (Beskid Makowski mts., Polish Outer Carpathians). Geochronometria 35: II-23. doi: I0.2478/viooo3-0IO-0009-I

Margielewski, W., Kołaczek, P., Michczyński, A., Obidowicz, A. and Pazdur, A. 20Ir. Record of the Meso- and Neoholocene palaeoenvironmental changes in the Jesionowa landslide peat bog (Beskid Sądecki Mts. Polish Outer Carpathians). Geochronometria 38: I38-I54. doi: I0.2478/ sI3386-OII-OOI4-9

Michno, A. 2004. Transformacja doliny dolnej Nidzicy w holocenie. Kraków.

Milisauskas, S. and Kruk, J. 1984. Settlement organization and the appearance of low level hierarchical societies during the Neolithic in the Bronocice microregion, southeastern Poland. Germania 62: I-30.

Milisauskas, S. and Kruk, J. 1989. Economy, migration, settlement organization, and warfare during the Late Neolithic in Southeastern Poland. Germania 67: 77-96.

Milisauskas, S., Kruk, J., Pipes, M.-L. and Haduch, E. 2016. Neolithic Human Burials Practices. The Interpretation of Funerary Behaviors at Bronocice. Kraków.

Moskal-del Hoyo, M., Wacnik, A., Alexandrowicz, W. P., Stachowicz-Rybka, R., Wilczyński, J., Pospuła-Wędzicha, S., Szwarczewski, P., Korczyńska, M., Cappenberg, K. and Nowak, M. 20I8. Open country species persisted in loess regions during the Atlantic and early Subboreal phases: New multidisciplinary data from southern Poland. Review of Palaeobotany and Palynology 253: 49-69. doi: 10.1016/j.revpalbo.2018.03.005

Mycielska, R. and Wałowy, A. 1964. Materiały z badań ratowniczych w Miechowie w 1958 i 1960 roku. Materiaty Archeologiczne 5: II9-I28.

Nalepka, D. 2003. Prehistoric and historic settlement recorded in a terrestrial pollen profile: Boreal to Subatlantic forest succession in a $60 \mathrm{~cm}$ thick sediment in Stanisławice (southern Poland). Acta Palaeobotanica 43: IOI-II2. 
Nalepka, D., Nowak, M. and Zając, M. 2005. Osadnictwo prehistoryczne i wczesnohistoryczne w zachodniej części Kotliny Sandomierskiej: konfrontacja danych archeologicznych i palinologicznych (stan badań do roku 2005). In M. Kuraś (ed.), Archeologia Kotliny Sandomierskiej, 97-134. Stalowa Wola.

Nowak, M. 200I. Osadnicze i socjo-polityczne modele południowo-wschodniej grupy kultury pucharów lejkowatych. In J. K. Kozłowski and E. Neustupný (eds), Archeologia przestrzeni. Metody i wyniki badań struktur osadniczych $w$ dorzeczach górnej Łaby $i$ Wisty, I27-I53. Kraków.

Nowak, M. 2004. Udział elementów lendzielsko-polgarskich w formowaniu się kultury pucharów lejkowatych w Małopolsce? Materiaty Archeologiczne Nowej Huty 24: I2I-I38.

Nowak, M. 2006. Results of the 1999 archaeological excavations at Gnojno, site 4, district of Busko-Zdrój, Świętokrzyskie voivodeship. Recherches Archeologiques de 1999-2003: 39-54.

Nowak, M. 2009. Drugi etap neolityzacji ziem polskich. Kraków.

Nowak, M. 20I4. Settlement and economic transformations in western Little Poland between 3500 and 2500 BC: internal development vs. external implantation. In T.L. Kienlin, P. Valde-Nowak, M. Korczyńska, K. Cappenberg and J. Ociepka (eds), Settlement, Communication and Exchange Around the Western Carpathians. International Workshop Held at the Institute of Archaeology, Jagiellonian University, Kraków October 27-28, 2012, I25-I42. Oxford.

Nowak, M. 20I7. Do I4C dates always turn into an absolute chronology? The case of the Middle Neolithic in western Lesser Poland. Documenta Praehistorica 44: 240-27I. doi: 10.4312/dp.44.I5

Nowak, M., Moskal-del Hoyo, M., Mueller-Bieniek, A., Lityńska-Zając, M. and Kotynia, K. 2017. Benefits and weaknesses of radiocarbon dating of plant material as reflected by Neolithic archaeological sites from Poland, Slovakia and Hungary. Geochronometria 44: I88-20I. doi: I0.1515/ geochr-2015-0066

Nowak, M. and Rodak, T. (eds) 2015. Osady z epoki kamienia oraz wczesnej epoki brazu na stanowiskach 9 i Io $w$ Stanistawicach, pow. bocheński. Kraków.

Poręba, G., Śnieszko, Z. and Moska, P. 20I2. New perspectives of dating prehistoric soil erosion in loess areas. Sprawozdania Archeologiczne 64: II3-I48.

Przybyła, M. M. and Tunia, K. 2013. Investigations in 2012 of the southern part of the Funnel Beaker culture temenos at Słonowice near the Małoszówka river. Fourth report. In S. Kadrow and P. Włodarczak (eds.), Environment and Subsistence - Forty Years After Janusz Kruk's "Settlement studies...", I39-162. Rzeszów-Bonn.

Radwański, K. 1957. Osada neolityczna w miejscowości Prandocin, pow. Miechów. Wiadomości Archeologiczne 24: I43-I44.

Reimer, P. J., Bard, E. and Bayliss, A. et al. 20I3. IntCalı3 and Marineı3 radiocarbon age calibration curves O-50,000 years cal BP. Radiocarbon 55: I869-I887. doi: I0.2458/azu_js_rc.55.I6947

Rook, E. 1980. Osadnictwo neolityczne w jaskiniach Wyżyny Krakowsko-Częstochowskiej. Materiaty Archeologiczne 20: 5-130.

Rook, E. and Nowak, M. 1993. Sprawozdanie z badań wielokulturowego stanowiska w Krakowie-Prądniku Czerwonym, w latach 1990 i 1991. Sprawozdania Archeologiczne 45: 35-72.

Rybicka, M., Głowacz, M. and Król, D. 20I7. Datowania radiowęglowe wielokulturowego cmentarzyska ze Skołoszowa, stanowisko 7, pow. jarosławski, woj. podkarpackie. In M. Rybicka (ed.), Wielokulturowe cmentarzysko $w$ Skotoszowie, stanowisko 7, pow. jarostawski, w kontekście osadnictwa z neolitu i wczesnej epoki brązu we wschodniej części Podgórza Rzeszowskiego, II3-I42. Rzeszów.

Rydzewski, J. 1972. Badania poszukiwawcze i weryfikacyjne w dolnym dorzeczu Szreniawy. Sprawozdania Archeologiczne 24: 267-294.

Rydzewski, J. 1973. Badania poszukiwawcze i weryfikacyjne w dorzeczu Małoszówki. Sprawozdania Archeologiczne 25: 243-260. 
Ioo $\mid$ Marek Nowak

Szwarczewski, P. 2009. The formation of deluvial and alluvial cones as a consequence of human settlement on a loess plateau: an example from the Chroberz area (Poland). Radiocarbon 51: 445-455. doi: IO.IOI7/sO033822200055843

Tunia, K. 1990. Archäologische Untersuchungen am neolitischen Verteidigungswerk bei Słonowice, Woj. Kielce, in den Jahren 1979-1988. 2. Vorbericht. Jahresschrift für mitteldeutsche Vorgeschichte 73: 249-254.

Tunia, K. 2006. "Temenos” kultury pucharów lejkowatych w Słonowicach, pow. Kazimierza Wielka. Badania 1979-2002. Trzecie sprawozdanie. In J. Libera and K. Tunia (eds), Idea megalityczna w obrządku pogrzebowym kultury pucharów lejkowatych, 335-340. Lublin-Kraków.

Tunia, K. and Włodarczak, P. 20II. Tumulus of the Funnel Beaker Culture in Malżyce, Kazimierza Wielka District. Sprawozdania Archeologiczne 63: 203-220.

Valde-Nowak, P. 1988. Etapy i strefy zasiedlenia Karpat polskich w neolicie i na początku epoki brązu. Wrocław-Warszawa-Kraków-Gdańsk-Łódź.

Wawrzeniecki, M. 1898. Poszukiwania archeologiczne w Lelowicach i Mieroszowie w guberni kieleckiej. Materyaty Antropologiczno-Archeologiczne i Etnograficzne 3: 5I-56.

Wawrzeniecki, M. 1900. Zabytki przedhistoryczne w pow. Miechowskim gub. Kieleckiej. Światowit 2: $8 \mathrm{I}-85$.

Wiślański, T. 1979. Kształtowanie się miejscowych kultur rolniczo-hodowlanych. Plemiona kultury pucharów lejkowatych. In W. Hensel and T. Wiślański (eds), Neolit, i65-260. Wrocław-WarszawaKraków-Gdańsk-Łódź. Prahistoria Ziem Polskich. Tom II.

Włodarczak, P. 2006. Chronologia grupy południowo-wschodniej kultury pucharów lejkowatych w świetle dat radiowęglowych. In J. Libera and K. Tunia (eds), Idea megalityczna w obrządku pogrzebowym kultury pucharów lejkowatych, 22-66. Lublin-Kraków.

Włodarczak, P. 2008a. Absolute chronology of the barrow in Kolosy. Sprawozdania Archeologiczne 6o: I5I-I68.

Włodarczak, P. 2008b. Corded Ware and Baden Cultures. Outline of chronological and genetic relations based on finds from western Little Poland. In M. Furholt, M. Szmyt and A. Zastawny (eds), The Baden Complex and the Outside World. Proceedings of the I2th Annual Meeting of the EAA in Cracow I9-24th September 2006, 247-262. Bonn.

Zastawny, A. 2008. The Baden and the Funnel Beaker-Baden settlement in Lesser Poland. In M. Furholt, M. Szmyt and A. Zastawny (eds.), The Baden Complex and the Outside World. Proceedings of the I2th Annual Meeting of the EAA in Cracow I9-24th September 2006, I77-188. Bonn.

Zastawny, A. 20II. Chronologia i formy oddziaływań kompleksu badeńskiego w Małopolsce. In M. Popelka and R. Šmidtová (eds.), Otázky neolitu a eneolitu našich zemi - 2009, Mělník 28.9. I.I0.2009., 43I-450. Praha.

Zastawny, A. 20I4. Neolityczne osadnictwo strefy "piaskowej” południowego obrzeżenia doliny Wisły pod Krakowem w świetle badań na stanowisku I3 w Kokotowie, gm. Wieliczka, woj. małopolskie. Raport 9: II-52.

Zastawny, A. 20I5a. The Baden complex in Lesser Poland - horizons of cultural influences. In M. Nowak and A. Zastawny (eds.), The Baden Culture Around the Western Carpathians, II9-150. Kraków.

Zastawny, A. 20I5b. Absolute chronology of the Baden culture in Lesser Poland - new radiocarbon dates. In M. Nowak and A. Zastawny (eds.), The Baden Culture Around the Western Carpathians, I9I-2I9. Kraków.

Zastawny, A. 2018. Pre-Baden cultural horizon in the Eneolithic of western Lesser Poland. In P. ValdeNowak, K. Sobczyk, M. Nowak and J. Źrałka (eds), Multas per Gentes et Multa per Saecula. Amici Magistro et Collegae Suo Ioanni Christopho Koztowski Dedicant, 495-502. Kraków. 
Zastawny, A. and Grabowska, B. 20II. Zespoły typu Modlnica z ceramiką ściegu bruzdowego (Furchenstichkeramik) ze st. 5 w Modlnicy, pow. krakowski. In J. Kruk and A. Zastawny (eds), Modlnica, st. 5. Od neolitu środkowego do wczesnej epoki brązu, I7I-229. Kraków.

Zastawny, A., Włodarczak, P. and Grabowska, B. 2oIr. Osada kultury pucharów lejkowatych w Modlnicy, pow. krakowski. In J. Kruk and A. Zastawny (eds), Modlnica, st. 5. Od neolitu środkowego do wczesnej epoki brązu, 23I-290. Kraków. 
